PYTHAGORAS: Jurnal Pendidikan Matematika

Volume 10 - Nomor 2, Desember 2015, (117-128)

Available online at: http://journal.uny.ac.id/index.php/pythagoras

\title{
Pengembangan Perangkat Pembelajaran Matematika untuk SMP Kelas VII Semester Genap dengan Pendekatan Saintifik
}

\author{
Bayu Prasetyo ${ }^{1)}$, Rusgianto Heri Santosa ${ }^{2)}$ \\ ${ }^{1}$ SMP Negeri 2 Rumpin Kabupaten Bogor. Jalan Raya Cicangkal, Kecamatan Rumpin, Kabupaten \\ Bogor, Jawa Barat, Indonesia. Email: bayuprasetyo1304@gmail.com \\ ${ }^{2}$ Pendidikan Matematika, Universitas Negeri Yogyakarta, Jl. Colombo No. 1, Karangmalang, \\ Yogyakarta 55281, Indonesia. Email: santosa_rh@yahoo.co.id
}

\begin{abstract}
Abstrak
Tujuan penelitian ini adalah menghasilkan produk berupa perangkat pembelajaran matematika untuk SMP kelas VII semester genap dengan pendekatan saintifik yang meliputi RPP, LKS, dan instrumen penilaian hasil belajar siswa yang valid, praktis, dan efektif. Model pengembangan yang digunakan dalam penelitian ini adalah model pengembangan Four-D yang meliputi empat tahap yaitu: (1) pendefinisian, (2) perancangan, (3) pengembangan, dan (4) penyebaran. Tidak semua produk dilakukan uji pengembangan. Uji pengembangan produk hanya dilakukan pada materi persamaan dan pertidaksamaan linear satu vaiabel. Hasil penelitian menunjukkan bahwa produk yang telah dilakukan uji pengembangan memenuhi kriteria valid, praktis, dan efektif. Produk memenuhi kriteria valid berdasarkan persentase penilaian ahli mencapai $100 \%$. Produk memenuhi kriteria praktis berdasarkan penilaian guru dan siswa yang termasuk dalam kategori sangat baik, serta berdasarkan hasil observasi keterlaksaan pembelajaran. Produk memenuhi kriteria efektif berdasarkan hasil belajar siswa pada kompetensi sikap, pengetahuan, dan keterampilan. Persentase siswa yang mencapai KKM untuk kompetensi sikap, pengetahuan, dan keterampilan melebihi $75 \%$.
\end{abstract}

Kata Kunci: pengembangan, perangkat pembelajaran, pendekatan saintifik

\section{Developing Mathematics Instructional Materials for $7^{\text {th }}$ Grade Students of Junior High School in Second Semester Based on the Scientific Approach}

\begin{abstract}
The aim of this study is to produce mathematics instructional materials for $7^{\text {th }}$ grade students of junior high school in their second semester based on the scientific approach including lesson plans, student's worksheets, and assessment instrument of learning achievement that fulfill the quality criteria of validity, practicality, and effectiveness. This research was a development study using the Four-D development model with four steps: (1) define, (2) design, (3) develop, and (4) disseminate. Development test was not done for all products. Development testing of product was done only for linear equality and inequality with one variable. The result of the study shows that the product which has done development test is valid, practical, and effective. The product fulfills the validity criterion. It is shown by the percentage of experts' appraisal which reaches $100 \%$ that belongs to a valid category. The product fulfills the practicality criterion based on teacher and student assesment to the instructional material that is in a very good category. The product also fulfills the practicality criterion based on the percentage of teaching implementation. The percentage of teaching implementation exceeded 90\%. The product fulfills the effectiveness criterion based on student learning achievement in attitude, knowledge, and skill competency. The percentage of students that achieve minimum mastery criteria for attitude, knowledge, and skill competency exceeded $75 \%$.
\end{abstract}

Keywords: development, instructional material, scientific approach

How to Cite Item: Prasetyo, B., \& Santosa, R. (2015). Pengembangan perangkat pembelajaran matematika untuk SMP kelas VII semester genap dengan pendekatan saintifik. PYTHAGORAS: Jurnal Pendidikan Matematika, 10(2), 117-128. Retrieved fromhttp://journal.uny.ac.id/index.php/pythagoras/article/view/9122 


\section{Pythagoras, 10 (2), Desember 2015 - 118}

Bayu Prasetyo, Rusgianto Heri Santosa

\section{PENDAHULUAN}

Seiring dengan berkembangnya ilmu pengetahuan dan teknologi, kualitas pendidikan juga perlu ditingkatkan. Kualitas pendidikan dapat ditingkatkan melalui peningkatan kualitas pembelajaran. Pembelajaran merupakan kegiatan yang dirancang untuk memfasilitasi proses belajar siswa (Schunk, 2012, p.222). Menurut Huitt (2003, p.1), pembelajaran adalah salah satu kegiatan utama guru di kelas sebagai arah tujuan dari proses belajar.

Matematika adalah mata pelajaran yang sangat penting untuk dipelajari dan dikuasai dengan baik, karena matematika merupakan ilmu yang memegang peranan penting dalam perkembangan teknologi modern dan berpengaruh terhadap perkembangan daya pikir siswa. Di sekolah, matematika wajib diajarkan pada pendidikan dasar (SD) dan pendidikan menengah (SMP dan SMA). Menurut Kennedy, et al (2008, p.55), pembelajaran matematika yang baik ialah pembelajaran matematika yang berorentasi pada siswa, bukan berorientasi pada guru. Pembelajaran matematika yang efektif dapat dilakukan melalui penemuan terbimbing, pembelajaran bermakna, dan pemecahan masalah.

Di tingkat SMP, mata pelajaran matematika merupakan salah satu mata pelajaran yang wajib diajarkan dan menjadi syarat kelulusan bagi siswa yang ingin melanjutkan ke jenjang pendidikan yang lebih tinggi. Selain itu, materi-materi untuk SMP merupakan materimateri yang cukup essensial dalam pembelajaran matematika karena akan menjadi dasar atau prasyarat untuk penguasaan materi di jenjang yang lebih tinggi, terutama pada kelas VII SMP. Namun pada kenyataannya mata pelajaran matematika justru menjadi mata pelajaran yang sulit untuk dimengerti dan dipahami oleh siswa SMP kelas VII. Indikasi kesulitan belajar matematika siswa SMP kelas VII ini dapat dilihat dari nilai Ujian Akhir Semester (UAS) kelas VII yang cenderung masih rendah.

Keberhasilan siswa dalam belajar akan terwujud dari keberhasilan proses pembelajaran yang meliputi perencanaan, pelaksanaan, dan evaluasi. Proses pembelajaran pada satuan pendidikan harus dilaksanakan secara interaktif, inspiratif, menyenangkan, menantang, dan mampu untuk memotivasi siswa agar mampu berpartisipasi secara aktif.

Menurut Uno (2014, p.2), pembelajaran memiliki hakikat perencanaan atau perancangan/ desain sebagai upaya untuk membelajarkan siswa. Berdasarkan hal tersebut, maka salah satu cara untuk meningkatkan kualitas pembelajaran matematika adalah dengan merencanakan kegiatan pembelajaran yang berpusat pada siswa dimana siswa merupakan subjek pembelajaran, sehingga dalam pembelajaran siswa mampu berperan aktif untuk mencapai kompetensi yang harus dimilikinya. Dengan adanya perencanaan maka pembelajaran semakin terarah dan guru memiliki panduan pembelajaran yang akan dilaksanakan. Kesalahan guru pada saat pembelajaran pun dapat diminimalisir dengan perencanaan yang telah dipersiapkan sebelum pembelajaran (Muslich, 2007, p.45).

Untuk melaksanakan proses pembelajaran diperlukan peran guru dalam memberikan keteladanan, membangun kemauan, mengembangkan potensi, dan kreativitas siswa. Kemauan membangun dan mengembangkan potensi siswa dapat dilakukan dengan memfasilitasi dan memberikan arahan kepada siswa. Peran guru sebagai fasilitator adalah memberikan kesempatan kepada siswa untuk berkembang sesuai dengan potensinya. Berdasarkan hal tersebut, maka guru perlu memberikan kesempatan yang luas kepada siswa untuk menggali kemampuannya dalam mempelajari matematika namun tetap dalam bimbingan guru. Salah satu solusi yang dapat dipertimbangkan adalah dengan penggunaan lembar kegiatan siswa (LKS). Penggunaan LKS dalam kegiatan pembelajaran dapat mendorong siswa untuk mengolah sendiri bahan yang dipelajari atau bersama dengan temannya dalam suatu bentuk diskusi kelompok. LKS juga dapat memberi peluang bagi siswa untuk mengembangkan kreativitasnya, walaupun masih ada peranan guru dalam memberikan arahan.

Pemerintah akan memberlakukan kurikulum baru (Kurikulum 2013) sebagai upaya untuk mencapai tujuan pendidikan nasional yang sesuai dengan perkembangan zaman. Kurikulum 2013 mulai diimplementasikan pada tahun ajaran 2014/2015, semua sekolah di setiap jenjang harus melaksanakannya. Salah satu alasan pemerintah mengembangkan kurikulum 2013 adalah semangat perubahan proses pembelajaran dan proses penilaian.

Pendekatan pembelajaran yang digunakan dalam kurikulum 2013 adalah pendekatan saintifik. Pendekatan saintifik sendiri tidak dapat lepas dari metode saintifik. Menurut D'Amico, et al (2010, p.34), metode saintifik adalah metode ilmiah yang sering digunakan para ilmuwan untuk menganalisis masalah dan 


\section{Pythagoras, 10 (2), Desember 2015 - 119}

Bayu Prasetyo, Rusgianto Heri Santosa

menemukan penyelesaiannya secara ilmiah. Pembelajaran dengan pendekatan saintifik adalah proses pembelajaran yang mengadopsi langkah-langkah para ilmuwan dalam membangun pengetahuan melalui proses berpikir logis dan metode ilmiah.

Tujuan pembelajaran dengan pendekatan saintifik didasarkan pada keunggulan pendekatan tersebut. Beberapa tujuan pembelajaran dengan pendekatan saintifik adalah: (1) Meningkatkan kemampuan intelek, khususnya kemampuan berpikir tingkat tinggi siswa. (2) Membentuk kemampuan siswa dalam menyelesaikan suatu masalah secara sistematik. (3) Terciptanya kondisi pembelajaran dimana siswa merasa bahwa belajar itu merupakan suatu kebutuhan. (4) Diperolehnya hasil belajar yang tinggi. (5) Melatih siswa dalam mengomunikasikan ide-ide, khususnya dalam menulis artikel ilmiah. (6) Mengembangkan karakter siswa.

Lebih lanjut, Kemdikbud (2013, p.187) menyatakan bahwa proses pembelajaran dengan pendekatan saintifik menyentuh tiga ranah, yaitu sikap, pengetahuan, dan keterampilan, sehingga pembelajaran dengan pendekatan saintifik diyakini dapat mengembangkan sikap, pengetahuan, dan keterampilan siswa. Secara teknis menurut Peraturan Menteri Pendidikan dan Kebudayaan Nomor 103 Tahun 2014, pendekatan saintifik dalam proses pembelajaran terdiri atas lima kegiatan yaitu mengamati, menanya, mengumpulkan informasi, mangasosiasi, dan mengkomunikasikan.

Guna mencapai tujuan pembelajaran, selama proses pembelajaran guru mempunyai peran sentral yaitu sebagai perencana, pelaksana, dan evaluator. Undang-undang Nomor 14 Tahun 2005 tentang Guru dan Dosen pada Pasal 20 dinyatakan bahwa dalam melaksanakan tugas keprofesionalan, guru berkewajiban merencanakan pembelajaran, melaksanakan proses pembelajaran yang bermutu, serta menilai dan mengevaluasi hasil pembelajaran.

Dalam pelaksanaan proses pembelajaran yang akan berlangsung, guru perlu menyusun perangkat pembelajaran dengan baik. Perangkat pembelajaran adalah sekumpulan sumber belajar yang memungkinkan guru dan siswa melakukan kegiatan pembelajaran (Ormrod, 2003, p.429). Menurut Nwike, et al (2013, p.103), perangkat pembelajaran adalah alat bantu mengajar atau peralatan yang digunakan guru di dalam kelas untuk memfasilitasi pembelajaran dalam rangka mencapai tujuan yang diharapkan. Perangkat pembelajaran dapat digunakan sebagai panduan pembelajaran sehingga pembelajaran menjadi terarah menuju kompetensi yang akan dituju. Perangkat pembelajaran juga dapat digunakan sebagai patokan evaluasi pembelajaran.

Pada waktu pra-survey, diketahui bahwa ternyata masih terdapat banyak masalah berkaitan dengan implementasi kurikulum 2013 khususnya dalam pembelajaran matematika SMP. Permasalahan ditambah lagi dengan kurang tersedianya media atau sumber belajar untuk pembelajaran matematika dengan pendekatan saintifik. Guru-guru belum mampu mengembangkan perangkat pembelajaran matematika dengan pendekatan saintifik secara mandiri, sehingga ketersediaannya masih kurang. Guru-guru cenderung hanya menggunakan perangkat pembelajaran hasil mengunduh dari internet, sehingga pembelajaran matematika dengan pendekatan saintifik yang seharusnya dapat mendorong siswa untuk membangun pengetahuan dan mengungkapkan ide-ide menjadi tidak optimal.

Hal tersebut diperkuat dengan penelitian yang dilakukan oleh Rusindrayanti $(2015,1)$ yang mengevaluasi pelaksanaan Kurikulum 2013 dilihat dari segi pemahaman guru matematika terhadap penyusunan perangkat pembelajaran matematika dengan pendekatan saintifik, implementasi pendekatan saintifik pada pembelajaran matematika kelas VII, dan hambatan serta solusi yang ditemukan dalam pelaksanaan pembelajaran dengan menggunakan pendekatan saintifik dalam mata pelajaran matematika kelas VII. Hasil penelitian menunjukkan bahwa terdapat hambatan pada pembuatan RPP karena tidak ada pedoman yang pasti dan pada pelaksanaan pembelajaran. yaitu kesulitan dalam membuat instrumen pembelajaran, kesulitan dalam melaksanakan pembelajaran dengan langkah 5M, serta kesulitan dalam melakukan penilaian.

Oleh karena itu, akan dilakukan penelitian pengembangan untuk menghasilkan produk berupa perangkat pembelajaran matematika dengan pendekatan saintifik yang valid, praktis, dan efektif. Penelitian pengembangan adalah suatu proses atau langkah-langkah untuk mengembangkan suatu produk baru atau menyempurnakan produk yang telah ada yang dapat dipertanggungjawabkan (Sukmadinata, 2006, p.164). Menurut Gay (1981, p.10), penelitian pengembangan bukan untuk menguji teori tetapi mengembangkan secara efektif produk yang digunakan di sekolah. Produk yang dihasilkan dapat berupa materi pelatihan guru, materi 
pelajaran, sejumlah tujuan behavioral, media dan sistem manajemen.

Perangkat pembelajaran yang dikembangkan dalam penelitian ini meliputi rencana pelaksanaan pembelajaran (RPP), lembar kegiatan siswa (LKS), dan instrumen penilaian hasil belajar siswa. Komponen perangkat pembelajaran matematika yang dikembangkan tersebut dapat dirinci sebagai berikut: (1) RPP, merupakan rencana yang menggambarkan prosedur dan pengorganisasian pembelajaran untuk mencapai satu kompetensi dasar yang ditetapkan dalam standar isi. (2) LKS, merupakan lembaran-lembaran yang berisi petunjuk belajar atau langkah-langkah kegiatan belajar bagi siswa untuk menemukan/memperoleh pengetahuan dari materi yang sedang dipelajari. Materi dalam LKS disusun sedemikian rupa sehingga dengan mempelajari materi tersebut tujuan-tujuan pembelajaran yang telah dirumuskan dapat tercapai. Materi pembelajaran itu disusun langkah demi langkah secara teratur dan sistematik sehingga siswa dapat mengikutinya dengan mudah. LKS juga disertai dengan pertanyaan/latihan dan biasanya melampirkan jawaban yang benar. (3) Instrumen penilaian yang dikembangkan merupakan alat yang digunakan untuk menilai kompetensi sikap, pengetahuan, dan keterampilan dengan metode penilaian yang dipilih. Instrumen penilaian dapat dilengkapi dengan pedoman penilaian.

Perangkat pembelajaran matematika dikembangkan menggunakan pendekatan saintifik. Penelitian ini dilakukan sebagai upaya mendukung terlaksananya pembelajaran matematika yang lebih optimal.

\section{METODE}

\section{Model Pengembangan}

Penelitian ini merupakan penelitian pengembangan. Pada penelitian ini yang dilakukan adalah mengembangkan perangkat pembelajaran matematika untuk SMP kelas VII semester genap dengan pendekatan saintifik. Perangkat pembelajaran yang dikembangkan meliputi Rencana Pelaksanaan Pembelajaran (RPP), Lembar Kegiatan Siswa (LKS), dan Instrumen Penilaian Hasil Belajar Siswa.

Model pengembangan yang digunakan dalam penelitian ini adalah model pengembangan Four-D. Model pengembangan Four-D dikembangkan oleh Thiagarajan, et al (174; p.5). Model pengembangan Four-D meliputi empat tahapan yaitu: pendefinisian (define), perancang- an (design), pengembangan (develop), dan penyebaran (disseminate).

\section{Prosedur Pengembangan}

Tahap-tahap yang dilakukan dalam penelitian ini adalah tahap pendefinisian (define), perancangan (design), pengembangan (develop), dan penyebaran (disseminate). Tahap pendefinisian bertujuan untuk menentukan dan mendefinisikan syarat-syarat pembelajaran. Kegiatan yang dilakukan dalam tahap pendefinisian adalah analisis awal-akhir, analisis siswa, analisis konsep/materi, analisis tugas, dan spesifikasi tujuan pembelajaran.

Tahap perancangan bertujuan untuk merancang perangkat pembelajaran matematika dan instrumen penelitian. Kegiatan yang dilakukan dalam tahap perancangan adalah mengkonstruksi tes menggunakan acuan kriteria, pemilihan media, pemilihan format, dan perancangan awal.

Tahap pengembangan bertujuan untuk menghasilkan perangkat pembelajaran yang telah direvisi berdasarkan masukan para ahli dan praktisi yang diperoleh dari uji coba. Kegiatan yang dilakukan dalam tahap pengembangan adalah validasi ahli dan uji pengembangan. Uji pengembangan sendiri terdiri atas dua kegiatan yaitu uji coba terbatas dan uji coba lapangan.

\section{Subjek Uji Coba}

Uji coba perangkat pembelajaran matematika yang dikembangkan dilakukan pada kelas VII SMP N 2 Rumpin, Kabupaten Bogor pada semester genap tahun ajaran 2014/2015.

Subjek uji coba dalam penelitian ini adalah guru matematika dan siswa kelas VII di SMP N 2 Rumpin, Kabupaten Bogor. Subjek uji coba terbatas adalah 1 guru matematika dan 6 siswa kelas VII yang memiliki tingkat kemampuan akademik tinggi, sedang, dan rendah masing-masing 2 siswa. Sedangkan subjek uji coba lapangan adalah 2 guru matematika dan 32 siswa kelas VII C. Pemilihan kelas VII C ini dilakukan secara acak.

\section{Data, Teknik, dan Intrumen Pengumpulan Data}

Jenis data dalam penelitian ini adalah data kualitatif dan kuantitatif. Data-data ini bertujuan untuk mendapatkan gambaran kualitas produk yang dikembangkan. Data kualitatif diperoleh dari komentar dan saran perbaikan baik dari validator, guru, maupun siswa. Sedangkan data kuantitatif diperoleh dari skor penilaian guru 
dan siswa terhadap kepraktisan perangkat pembelajaran, hasil observasi pelaksanaan pembeljaran, dan tes hasil belajar.

Pada penelitian pengembangan ini, peneliti menggunakan beberapa instrumen penelitian yang digunakan untuk mengumpulkan data tentang kevalidan, kepraktisan, dan keefektifan produk. Instrumen penilaian kevalidan produk yang dikembangkan terdiri atas lembar validasi RPP, lembar validasi LKS, dan lembar validasi instrumen penilaian hasil belajar. Instrumen penilaian kepraktisan produk terdiri atas lembar penilaian guru terhadap kepraktisan produk, lembar penilaian siswa terhadap keterbacaan produk, lembar penilaian siswa terhadap kepraktisan produk, dan lembar observasi pelaksanaan pembelajaran. Instrumen penilaian keefektifan produk terdiri atas instrumen penilaian hasil belajar siswa yang meliputi kompetensi sikap, pengetahuan, dan keterampilan.

\section{Teknik Analisis Data}

Teknik analisis data pada penelitian ini dilakukan untuk menentukan apakah produk yang dikembangkan memenuhi syarat kevalidan, kepraktisan, dan keefektifan. Data yang didapatkan dalam penelitian ini adalah data yang bersumber dari instrumen penelitian. Data yang berupa komentar dan saran perbaikan dianalisis secara deskriptif kualitatif dan disimpulkan sebagai bahan untuk merevisi produk yang dikembangkan. Sedangkan data yang berupa skor penilaian guru, skor penilaian siswa, dan hasil belajar siswa dianalisis secara deskriptif kuantitatif.

Teknik analisis data dalam penelitian ini secara rinci meliputi teknik analisis data kevalidan, kepraktisan, dan keefektifan produk. Untuk teknik analisis data kevalidan, produk dikatakan valid jika semua aspek penilaian kevalidan dinyatakan valid oleh validator.

Data mengenai kepraktisan produk terdiri data hasil penilaian guru, penilaian siswa, dan observasi pelaksanaan pembelajaran matematika menggunakan produk yang dikembangkan. Secara umum, analisis data kepraktisan produk dilakukan dengan cara mengelompokkan data yang diperoleh berdasarkan produk, kemudian melakukan perhitungan rata-rata skor. Selanjutnya skor rata-rata tersebut diubah ke dalam data kualitatif dengan kriteria seperti Tabel 1.
Tabel 1. Kriteria Penilaian Kepraktisan Produk

\begin{tabular}{cc}
\hline \multicolumn{1}{c}{ Interval } & Kriteria \\
\hline$M_{i}+1,8 S d i<\bar{M}$ & Sangat mudah \\
$\leq M_{i}+3,0 S d i$ & dilaksanakan \\
$M_{i}+0,6 S d i<\bar{M}$ & Mudah dilaksanakan \\
$\leq M_{i}+1,8 S d i$ & Cukup dapat \\
$M_{i}-0,6 S d i<\bar{M}$ & dilaksanakan \\
$\leq M_{i}+0,6 S d i$ & Kurang dapat \\
$M_{i}-1,8 S d i<\bar{M}$ & dilaksanakan \\
$\leq M_{i}-0,6 S d i$ & Sulit dilaksanakan \\
$M_{i}-3,0 S d i<M$ & \\
$\leq M_{i}-1,8 S d i$ &
\end{tabular}

Sumber: Widoyoko (2014; p.238)

Analisis data keefektifan produk dilakukan terhadap hasil belajar siswa yang meliputi kompetensi sikap, pengetahuan dan keterampilan. Untuk kompetensi sikap, hasil belajar dikatakan tuntas secara individual jika mencapai KKM yang ditetapkan sekolah yaitu B (baik). Ketuntasan secara klasikal tercapai jika $75 \%$ siswa mencapai kriteria ketuntasan individual. Untuk kompetensi pengetahuan dan keterampilan, hasil belajar dikatakan tuntas secara individual jika mencapai KKM yang ditetapkan sekolah yaitu 2,67. Ketuntasan secara klasikal tercapai jika 75\% siswa mencapai kriteria ketuntasan individual. Produk yang dikembangkan dikatakan efektif jika kriteria ketuntasan secara klasikal pada kompetensi sikap, pengetahuan, dan keterampilan tercapai.

\section{HASIL DAN PEMBAHASAN}

\section{Analisis Awal-Akhir}

Analisis awal-akhir dalam penelitian ini dilakukan untuk menganalisis permasalahan terkait dengan pembelajaran matematika sehingga diperlukan pengembangan perangkat pembelajaran matematika dengan pendekatan saintifik. Untuk itu observasi dilakukan dengan cara survey melalui diskusi dan wawancara dengan beberapa guru matematika SMP di kabupaten Bogor. Dari hasil tersebut diketahui beberapa masalah terkait dengan pembelajaran matematika terutama terkait dengan penyusunan perangkat pembelajaran, yaitu: (1) Guru cenderung masih menerapkan metode ceramah karena kegiatan pembelajaran yang berhubungan dengan pendekatan pembelajaran yang disusun guru dalam RPP tidak jelas. (2) LKS yang digunakan dalam kegiatan pembelajaran belum mampu memberikan kesempatan bagi siswa untuk melakukan aktivitas agar siswa mampu membangun pengertian dan mengkontruksi pengetahuannya secara mandiri, karena hanya 
berisi rangkuman materi dan soal-soal latihan. (3) Guru terlihat belum mampu melaksanakan penilaian sikap, pengetahuan, dan keterampilan. (4) Sebagian besar guru menggunakan perangkat pembelajaran hasil mengunduh dari internet atau menyalin berkas dari guru di sekolah lain.

Sehubungan dengan hal tersebut, maka peneliti memberikan solusi yaitu mengembangkan perangkat pembelajaran matematika untuk SMP kelas VII dengan pendekatan saintifik.

\section{Analisis Siswa}

Analisis siswa dalam penelitian ini dilakukan untuk menganalisis bagaimana karakteristik siswa pada jenjang SMP, khususnya siswa kelas VII di SMP N 2 Rumpin kabupaten Bogor sebagai subjek uji coba. Hasil analisis siswa adalah sebagai berikut: (1) Berdasarkan hasil diskusi dengan guru matematika di kelas VII SMP N 2 Rumpin kabupaten Bogor, tingkat kompetensi siswa cenderung berada pada kategori sedang. (2) Sesuai dengan perkembangan individu berdasarkan tingkat kognitif menurut Piaget (Slavin, 2006, p.33), siswa SMP berada pada tahap stadium operasional formal. Pada tahapan ini anak sudah mampu berpikir secara abstrak. Jika dikaitkan dengan pembelajaran matematika di kelas, maka pembelajaran dapat dilakukan dengan menyajikan suatu permasalahan. Namun permasalahan yang disajikan untuk siswa SMP tersebut sebaiknya merupakan permasalahan yang sering mereka temui dalam kehidupan sehari-hari.

\section{Analisis Konsep/Materi}

Analisis materi dalam penelitian ini dilakukan untuk memperoleh susunan materi yang akan diajarkan kepada siswa dengan cara mengidentifikasi, menyusun, dan merinci materi pembelajaran matematika kelas VII semester genap, kemudian menyajikannya secara sistematis. Berdasarkan kompetensi dasar yang harus dikuasai siswa pada semester genap sesuai dengan Peraturan Menteri Pendidikan dan Kebudayaan Nomor 58 Tahun 2014, materi pembelajaran matematika SMP kelas VII semester genap dapat disusun sebagai berikut: (1) segitiga dan segiempat, (2) persamaan dan pertidaksamaan linear satu variabel, (3) aritmetika sosial, (4) transformasi, (5) statistika, (6) peluang.

\section{Analisis Tugas}

Analisis tugas dalam penelitian ini dilakukan untuk menganalisis kegiatan-kegiatan siswa dalam pembelajaran matematika yang disesuaikan dengan pendekatan saintifik, sehingga diperoleh rincian mengenai tugas-tugas yang akan diberikan kepada siswa dalam pembelajaran. Secara umum kegiatan siswa dan rincian tugas untuk siswa dalam pembelajaran matematika dengan pendekatan saintifik meliputi lima langkah kegiatan yaitu: (1) Mengamati: siswa mengamati suatu permasalahan yang disajikan untuk mengidentifikasi hal-hal yang ingin diketahui. (2) Menanya: siswa membuat pertanyaan-pertanyaan tentang hal-hal yang tidak diketahui dari permasalahan yang diamati. (3) Mengumpulkan informasi: siswa melakukan eksperimen, membaca buku teks atau sumber lain, mengamati objek/kejadian/aktivitas, wawancara dengan nara sumber untuk mengumpulkan data/informasi yang relevan dengan pertanyaan. (4) Mengasosiasi: siswa mengolah informasi yang telah dikumpulkan untuk menjawab pertanyaan dan menarik kesimpulan. (5) Mengomunikasikan: siswa menyampaikan jawaban atau kesimpulan berdasarkan analisis secara lisan, tertulis, atau media lainnya.

Pada analisis tugas ini juga ditentukan indikator-indikator pencapaian kompetensi terkait materi pelajaran matematika SMP kelas VII semester genap yang diturunkan dari kompetensi inti dan kompetensi dasar.

\section{Spesifikasi Tujuan Pembelajaran}

Spesifikasi tujuan pembelajaran dilakukan untuk merumuskan tujuan pembelajaran berdasarkan indikator yang telah disusun. Tujuan pembelajaran yang disusun minimal memuat aspek audience (audien/siswa), behaviour (perilaku) dan condition (kondisi).

\section{Mengkonstruksi Tes Menggunakan Acuan Kriteria}

Pada penelitian ini, tes sudah tercakup dalam pengembangan instrumen penilaian, sehingga tahap mengkonstruksi tes menggunakan acuan kriteria termasuk dalam pengembangan instrumen penilaian yang mencakup aspek sikap, pengetahuan dan keterampilan.

\section{Pemilihan Media}

Pemilihan media dalam penelitian ini dilakukan untuk memilih perangkat pembelajaran matematika yang akan dikembangkan. Setelah melakukan analisis siswa, analisis konsep/materi, dan analisis tugas pada tahap pendefisian, maka perangkat pembelajaran matematika yang dikembangkan adalah RPP, LKS, dan instrumen penilaian hasil belajar siswa yang 


\section{Pythagoras, 10 (2), Desember 2015 - 123}

Bayu Prasetyo, Rusgianto Heri Santosa

meliputi kompetensi sikap, pengetahuan, dan keterampilan.

\section{Pemilihan Format}

Format dan karakteristik perangkat pembelajaran matematika yang dikembangkan adalah sebagai berikut: (1) Komponen RPP yang dikembangkan memuat identitas sekolah, identitas mata pelajaran, kelas/semester, materi pokok, alokasi waktu, kompetensi inti, kompetensi dasar, indikator pencapaian kompetensi, materi pembelajaran, metode pembelajaran, kegiatan pembelajaran, penilaian, pembelajaran remidial, pembelajaran pengayaan, media/alat, bahan, dan sumber belajar. (2) Komponen LKS yang dikembangkan memuat judul, tujuan pembelajaran, petunjuk belajar, langkah-langkah kegiatan, informasi pendukung, dan soal latihan. (3) Kegiatan pembelajaran yang dirancang dalam RPP dan bentuk kegiatan siswa yang dirancang dalam LKS disesuaikan dengan pendekatan pembelajaran yang digunakan yaitu pendekatan saintifik. (4) Perangkat pembelajaran dikembangkan berdasarkan pada tingkat kognitif untuk siswa SMP yaitu tahap operasional formal, namun masih perlu adanya bantuan visualisasi dalam menyajikan masalah. Visualisasi diharapkan dapat memudahkan siswa dalam memahami masalah. (5) Permasalahan yang disajikan disesuaikan dengan permasalahan yang sering ditemui siswa SMP.

Perancangan Awal

Perancangan awal dalam penelitian ini meliputi perancangan terhadap produk awal yaitu RPP, LKS, dan instrumen penilaian hasil belajar siswa. RPP merupakan rencana kegiatan pembelajaran yang dirancang untuk 35 pertemuan. Kegiatan pembelajaran yang dirancang dalam RPP disesuaikan dengan langkah-langkap pada pendekatan saintifik. LKS berisi kegiatankegiatan siswa yang meliputi permasalahan dan petunjuk/langkah penyelesaiannya yang akan dilakukan siswa dengan berdiskusi. LKS dirancang untuk setiap pertemuan pembelajaran sehingga ada 35 LKS yang dirancang seluruhnya. Instrumen penilaian dirancang untuk mengetahui sejauh mana pencapaian siswa pada kompetensi sikap, pengetahuan, dan keterampilan. Perangkat pembelajaran yang telah disusun pada tahap perancangan awal ini disebut sebagai draft 1 .

\section{Data Hasil Validasi Ahli}

Validasi dilakukan oleh ahli sebagai validator untuk melihat isi dari semua produk pada draft 1 dan memberikan penilaian terhadap kevalidan produk. Validasi juga bertujuan untuk mendapatkan masukan atau saran perbaikan dari validator baik secara tertulis maupun lisan. Validator dalam penelitian ini adalah dosen pendidikan matematika UNY, yaitu Ibu Dr. Heri Retnawati dan Bapak Drs. Edi Prajitno, M.Pd.

Berdasarkan hasil validasi, dapat disimpulkan bahwa perangkat pembelajaran matematika yang dikembangkan valid dan sudah siap digunakan untuk uji coba dengan menambahkan beberapa saran. Saran perbaikan dari validator tersebut menjadi dasar untuk melakukan revisi produk.

Perangkat pembelajaran matematika yang telah divalidasi disebut draft 2. Draft 2 selanjutnya dilakukan uji coba. Namun tidak semua produk dilakukan uji coba. Produk dari draft 2 dipilih satu produk sebagai sampel untuk dilakukan uji coba. Pemilihan sampel tersebut didasarkan pada materi pembelajaran matematika yang sedang dipelajari di kelas VII SMP N 2 Rumpin. Dalam penelitian ini, produk yang dilakukan uji coba adalah produk 2 (materi persamaan dan pertidaksamaan linear satu variabel).

\section{Data Hasil Uji Pengembangan}

Uji pengembangan pada penelitian ini meliputi uji coba terbatas dan uji coba lapangan. Uji coba terbatas bertujuan untuk menguji kualitas perangkat pembelajaran yang dikembangkan pada skala yang kecil. Sedangkan uji coba lapangan bertujuan untuk menguji kualitas perangkat pembelajaran yang dikembangkan pada skala yang lebih besar dilihat dari segi kepraktisan dan keefektifannya.

\section{Uji Coba Terbatas}

Uji coba terbatas dilakukan dalam dua tahap, yaitu uji coba awal dan uji coba kelompok kecil. Uji coba awal dilakukan untuk menguji kualitas perangkat pembelajaran matematika yang dikembangkan ditinjau dari segi keterbacaannya dengan cara meminta penilaian siswa. Sedangkan uji coba kelompok kecil dilakukan untuk menguji kualitas perangkat pembelajaran matematika yang dikembangkan ditinjau dari segi kepraktisannya dengan cara meminta penilaian guru dan siswa. 
Uji coba awal dilakukan dengan melibatkan enam siswa SMP N 2 Rumpin kelas VII yang memiliki tingkat kemampuan akademik tinggi, sedang, dan rendah. Keenam siswa tersebut diminta untuk membaca, mengamati, dan memahami segala sesuatu mengenai tugas di LKS yang harus dilaksanakan. Selanjutnya, keenam siswa tersebut memberikan penilaian terhadap keterbacaan perangkat pembelajaran matematika yang dikembangkan dengan cara mengisi lembar penilaian siswa terhadap keterbacaan dan menuliskan komentar di bagian keterangan. Hasil penilaian siswa terhadap keterbacaan ini menjadi bahan untuk melakukan revisi terhadap perangkat pembelajaran matematika yang dikembangkan sebelum dilakukan uji coba kelompok kecil.

Uji coba kelompok kecil dilakukan dengan melibatkan satu guru matematika di SMP N 2 Rumpin yaitu Ibu Susi Anggraeni, S.Pd dan enam siswa SMP N 2 Rumpin kelas VII yang memiliki tingkat kemampuan akademik tinggi, sedang, dan rendah. Pada uji coba kelompok kecil ini, guru melaksanakan pembelajaran matematika dengan menggunakan perangkat pembelajaran matematika yang dikembangkan kepada keenam siswa. Peneliti mendampingi dan membantu guru selama kegiatan tersebut agar seluruh kegiatan pembelajaran yang dilaksanakan oleh guru benar-benar sesuai dengan RPP yang dikembangkan. Selanjutnya, guru dan keenam siswa tersebut memberikan penilaian terhadap kepraktisan perangkat pembelajaran matematika yang dikembangkan dengan cara mengisi lembar penilaian terhadap kepraktisan. Selain itu guru dan keenam siswa tersebut juga diminta untuk memberikan komentar dan saran perbaikan. Komentar-komentar dan saran perbaikan ini menjadi bahan untuk melakukan revisi terhadap semua perangkat pembelajaran matematika yang dikembangkan sebelum dilakukan uji coba lapangan.

Uji Coba Lapangan

Uji coba lapangan melibatkan guru dan siswa. Dari segi guru, uji coba lapangan dilakukan pada dua orang guru matematika sebagai guru mitra dan observer yaitu Ibu Susi Anggraeni, S.Pd dan Bapak Haryadi Budi, S.T. Sedangkan dari segi siswa, uji coba lapangan dilakukan pada kelas VII SMP N 2 Rumpin yang dipilih satu kelas secara acak yaitu kelas VII C. Jumlah siswa sebanyak 32 siswa.

Kegiatan uji coba lapangan dilakukan dengan cara melaksanakan pembelajaran mate- matika di kelas VII C menggunakan produk yang dikembangkan oleh guru mitra. Selain melaksanakan kegiatan pembelajaran, selama pembelajaran berlangsung guru mitra memberikan penilaian terhadap sikap siswa menggunakan lembar observasi penilaian sikap. Sedangkan observer dengan dibantu oleh peneliti mengamati pelaksanaan kegiatan pembelajaran. Uji coba lapangan dilakukan dalam enam kali pertemuan dan satu kali tes.

Kepraktisan perangkat pembelajaran matematika yang dikembangkan diukur berdasarkan hasil penilaian guru dan siswa. Guru dan siswa memberikan penilaian, serta komentar dan saran perbaikan terhadap perangkat pembelajaran yang dikembangkan dengan cara mengisi lembar penilaian guru dan siswa terhadap kepraktisan produk. Sedangkan keefektifan perangkat pembelajaran matematika yang dikembangkan diukur berdasarkan hasil belajar siswa. Data hasil belajar siswa diperoleh berdasarkan hasil obervasi sikap dan tes tertulis siswa.

\section{Analisis Data Kevalidan Produk}

Perangkat pembelajaran matematika yang dikembangkan sudah layak digunakan untuk uji coba setelah dilakukan beberapa revisi berdasarkan komentar dan saran perbaikan dari validator. Penilaian validator untuk semua produk adalah valid sehingga dapat disimpulkan bahwa kevalidan perangkat pembelajaran matematika yang dikembangkan adalah valid. Hasil validasi produk dapat dilihat pada Tabel 2.

Table 2. Hasil Validasi Produk

\begin{tabular}{ccc}
\hline No. & Produk & Kevalidan \\
\hline 1. & RPP & Valid \\
2. & LKS & Valid \\
3. & IP Sikap & Valid \\
4. & IP Pengetahuan & Valid \\
5. & IP Keterampilan & Valid \\
\hline
\end{tabular}

\section{Analisis Data Kepraktisan Produk}

Kepraktisan perangkat pembelajaran matematika yang dikembangkan dalam penelitian ini didasarkan pada data hasil penilaian guru, hasil penilaian siswa, dan hasil observasi pelaksanaan pembelajaran.

Berdasarkan data hasil penilaian guru, dapat diketahui bahwa rata-rata skor tiap produk berada pada kategori "sangat mudah dilaksanakan". Hal ini berarti perangkat pembelajaran matematika yang dikembangkan praktis untuk 
digunakan. Hasil penilaian guru terhadap kepraktisan produk dapat dilihat pada Tabel 3.

Table 3. Hasil Penilaian Guru terhadap Kepraktisan Produk

\begin{tabular}{ccc}
\hline Produk & Rata-Rata Aktual & Kategori \\
\hline RPP & 57,5 & $\begin{array}{c}\text { Sangat mudah } \\
\text { dilaksanakan } \\
\text { Sangat mudah } \\
\text { dilaksanakan }\end{array}$ \\
$\begin{array}{c}\text { Instrumen } \\
\text { Penilaian }\end{array}$ & 62,0 & $\begin{array}{c}\text { Sangat mudah } \\
\text { dilaksanakan }\end{array}$ \\
\hline
\end{tabular}

Berdasarkan data hasil penilaian siswa, dapat diketahui bahwa banyaknya siswa yang menilai perangkat pembelajaran matematika pada kategori minimal "mudah digunakan" adalah 32, sehingga persentasenya adalah $100 \%$. Hal ini berarti perangkat pembelajaran matematika yang dikembangkan praktis karena persentase siswa yang menilai perangkat pembelajaran matematika pada kategori minimal "mudah digunakan" telah melebihi $75 \%$. Hasil penilaian siswa terhadap kepraktisan produk dapat dilihat pada Gambar 1.

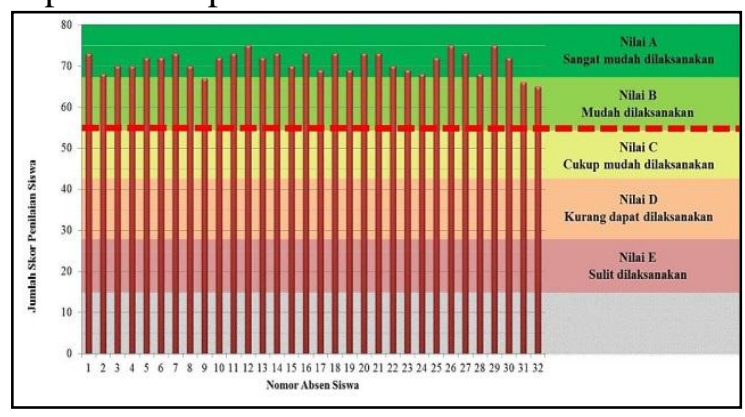

Gambar 1. Hasil Penilaian Siswa terhadap Kepraktisan Produk

Berdasarkan data hasil observasi pelaksanaan pembelajaran, dapat diketahui bahwa ratarata persentase keterlaksanaan pembelajaran untuk keenam pertemuan adalah 93,63\%. Tingkat keterlaksanaan ini sudah mencapai batas minimal dikatakannya produk yang dikembangkan praktis untuk digunakan. Hasil observasi pelaksanaan pembelajaran dapat dilihat Tabel 4.

Tabel 4. Hasil Observasi Pelaksanaan Pembelajaran

\begin{tabular}{cc}
\hline Pertemuan & Persentase Keterlaksanaan \\
\hline 1 & $82,35 \%$ \\
2 & $88,24 \%$ \\
3 & $97,06 \%$ \\
4 & $97,06 \%$ \\
5 & $97,06 \%$ \\
6 & $100 \%$ \\
Rata-Rata & $93,63 \%$ \\
\hline
\end{tabular}

\section{Analisis Data Keefektifan Produk}

Keefektifan perangkat pembelajaran matematika yang dikembangkan diukur berdasarkan hasil belajar siswa yang meliputi kompetensi sikap (spiritual dan sosial), pengetahuan, dan keterampilan.

Berdasarkan hasil belajar siswa pada kompetensi sikap, dapat diketahui bahwa nilai semua siswa pada kompetensi sikap telah mencapai KKM yang ditentukan sekolah yaitu minimal nilai B. Semua siswa telah mencapai ketuntasan individual atau dengan kata lain persentase ketuntasan secara klasikalnya adalah $100 \%$. Hal ini berarti perangkat pembelajaran matematika yang dikembangkan efektif karena persentase ketuntasan klasikal pada kompetensi sikap telah melebihi 75\%. Data pendukung lainnya adalah rata-rata nilai siswa pada kompetensi sikap secara klasikal. Rata-rata nilai siswa pada kompetensi sikap secara klasikal telah mencapai KKM yaitu 3,56 (nilai A). Hasil belajar siswa pada kompetensi sikap dapat dilihat pada Gambar 2.

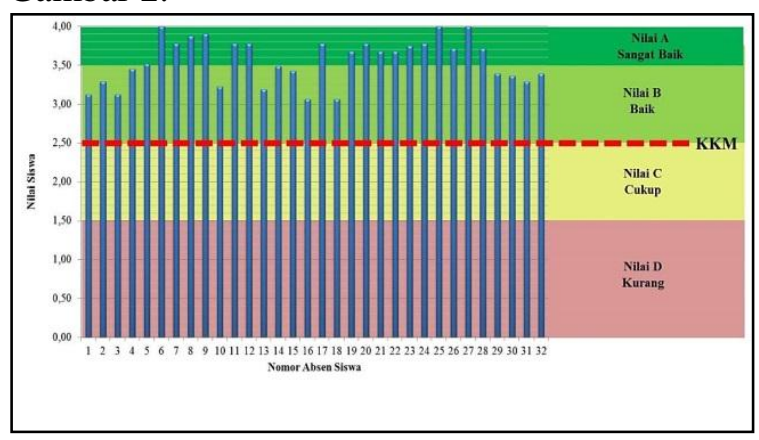

\section{Gambar 2. Hasil Belajar Siswa pada Kompetensi Sikap}

Berdasarkan hasil belajar siswa pada kompetensi pengetahuan, dapat diketahui bahwa terdapat 29 siswa yang nilainya telah mencapai KKM. Artinya terdapat 29 siswa yang telah mencapai ketuntasan individual, sehingga persentase ketuntasan secara klasikalnya adalah 90,63\%. Hal ini berarti perangkat pembelajaran matematika yang dikembangkan efektif karena persentase ketuntasan klasikal pada kompetensi pengetahuan telah melebihi $75 \%$. Data pendukung lainnya adalah rata-rata nilai siswa pada kompetensi pengetahuan secara klasikal. Ratarata nilai siswa pada kompetensi pengetahuan secara klasikal telah mencapai KKM yaitu 3,06 (nilai B). Hasil belajar siswa pada kompetensi pengetahuan dapat dilihat pada Gambar 3. 


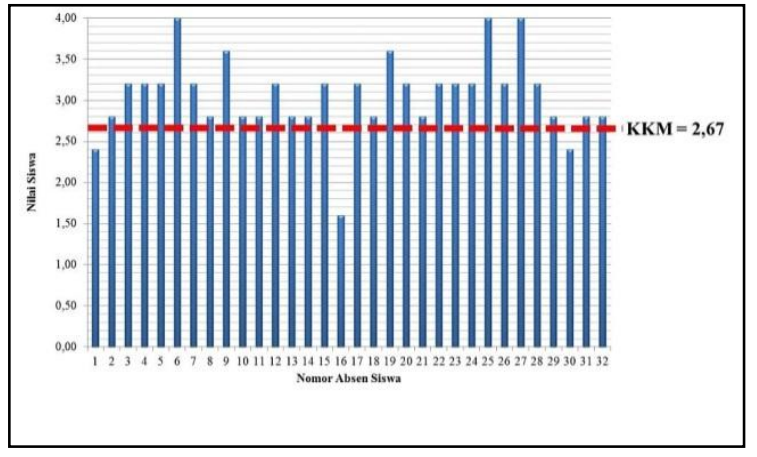

Gambar 3. Hasil Belajar Siswa pada Kompetensi Pengetahuan

Berdasarkan hasil belajar siswa pada kompetensi keterampilan, dapat diketahui bahwa terdapat 26 siswa yang nilainya telah mencapai KKM. Artinya terdapat 26 siswa yang telah mencapai ketuntasan individual, sehingga persentase ketuntasan secara klasikalnya adalah $81,25 \%$. Hal ini berarti perangkat pembelajaran matematika yang dikembangkan efektif karena persentase ketuntasan klasikal pada kompetensi keterampilan telah melebihi $75 \%$. Data pendukung lainnya adalah rata-rata nilai siswa pada kompetensi keterampilan secara klasikal. Ratarata nilai siswa pada kompetensi keterampilan secara klasikal telah mencapai KKM yaitu 3,33 (nilai $\mathrm{B}+$ ). Hasil belajar siswa pada kompetensi keterampilan dapat dilihat pada Gambar 4.

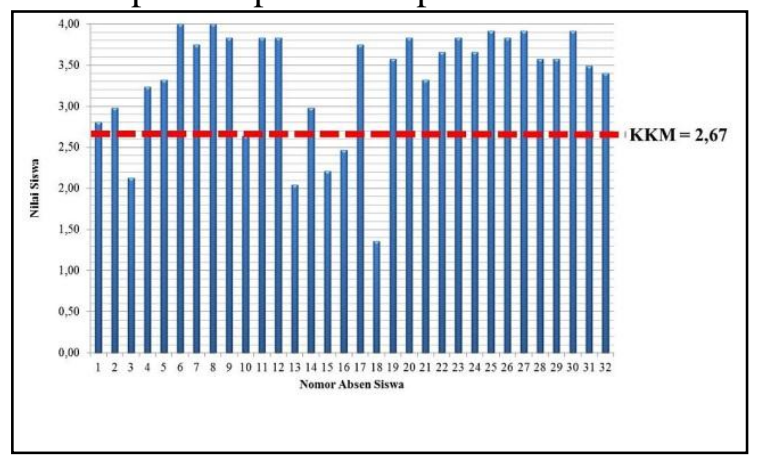

Gambar 4. Hasil Belajar Siswa pada Kompetensi Keterampilan

\section{Revisi Produk}

Pada tahap pengembangan produk, terdapat tiga tahap revisi produk. Revisi pertama dilakukan pada saat validasi, revisi kedua dilakukan setelah uji coba terbatas, dan revisi ketiga dilakukan setelah uji coba lapangan.

\section{Kajian Produk Akhir}

Berdasarkan analisis data, kualitas dan kelayakan produk akhir berupa perangkat pembelajaran matematika dengan pendekatan saintifik ditinjau dari tiga hal yaitu kevalidan, kepraktisan, dan keefektifan.

Produk yang dikembangkan telah memenuhi kriteria valid karena semua aspek pada setiap produk yang dikembangkan telah dinyatakan valid oleh ahli sebagai validator. Hal ini berarti produk yang dikembangkan sudah layak digunakan setelah dilakukan revisi atau perbaikan terlebih dahulu sesuai dengan saran dari validator.

Produk yang dikembangkan telah memenuhi kriteria praktis karena terdapat konsistensi antara penilaian guru dan siswa dengan kondisi penerapan di lapangan. Kepraktisan produk adalah sangat mudah dilaksanakan.

Produk yang dikembangkan telah memenuhi kriteria praktis efektif karena persentase ketuntasan klasikal pada kompetensi sikap, pengetahuan, dan keterampilan masing-masing telah melebihi 75\%. Ketercapaian KKM ini menunjukkan tingkat ketercapaian tujuan pembelajaran sehingga produk yang dikembangkan memenuhi kriteria efektif.

Telah terpenuhinya kriteria valid, praktis, dan efektif dari produk yang dikembangkan, maka diperoleh suatu produk akhir yaitu perangkat pembelajaran matematika untuk SMP kelas VII semester genap dengan pendekatan saintifik yang valid, praktis, dan efektif untuk digunakan dalam pembelajaran matematika di sekolah.

\section{Keterbatasan Penelitian}

Beberapa keterbatasan yang terdapat pada penelitian ini adalah sebagai berikut: (1) Perangkat yang dikembangkan hanya terdiri atas RPP, LKS dan instrumen penilaian. (2) Penelitian hanya dibatasi pada satu tingkat saja yaitu kelas VII SMP dan hanya dilakukan pada satu sekolah (SMP N 2 Rumpin Kabupaten Bogor) dengan mengambil satu kelas sebagai kelas uji coba. (3) Tidak semua produk dilakukan uji pengembangan. Uji pengembangan produk yang meliputi uji coba terbatas dan uji coba lapangan hanya dilakukan pada materi persamaan dan pertidaksamaan linear satu vaiabel. (4) Tahapan pengembangan produk tidak sampai ke tahap penyebaran (disseminate).

\section{SIMPULAN DAN SARAN}

\section{Simpulan tentang Produk}

Berdasarkan hasil penelitian, dapat diperoleh simpulan sebagai berikut: (1) Penelitian ini telah mengembangkan suatu produk yaitu 
perangkat pembelajaran matematika untuk SMP kelas VII semester genap dengan pendekatan saintifik yang terdiri atas RPP, LKS, dan instrumen penilaian kompetensi sikap, pengetahuan, dan keterampilan. Produk dikembangkan menggunakan model pengembangan Four-D yang meliputi empat tahap yaitu tahap pendefinisian, tahap perancangan, dan tahap pengembangan. (2) Produk yang dikembangkan memenuhi kriteria valid berdasarkan hasil validasi ahli. (3) Produk yang telah dilakukan uji pengembangan termasuk dalam kriteria praktis berdasarkan hasil penilaian guru, penilaian siswa, dan observasi pelaksanaan pembelajaran. (4) Produk yang telah dilakukan uji pengembangan termasuk dalam kriteria efektif berdasarkan hasil belajar siswa pada kompetensi sikap, pengetahuan, dan keterampilan.

\section{Saran Pemanfaatan Produk}

Saran pemanfaatan produk yang dikembangkan adalah sebagai berikut: (1) Produk berupa perangkat pembelajaran matematika untuk SMP kelas VII semester genap dengan pendekatan saintifik yang dikembangkan telah dinyatakan valid, praktis, dan efektif, sehingga dapat dimanfaatkan untuk pembelajaran di kelas. (2) Produk yang dikembangkan dapat dijadikan sebagai referensi dan bahan masukan bagi para guru dalam menyusun perangkat pembelajaran matematika. (3) Bagi peneliti lain, disarankan untuk mengembangkan perangkat pembelajaran matematika dengan penekatan saintifik pada jenjang lainnya.

\section{Diseminasi dan Pengembangan Produk Lebih Lanjut}

Produk berupa perangkat pembelajaran matematika untuk SMP kelas VII semester genap dengan pendekatan saintifik yang dikembangkan dapat disebarluaskan dan menjadi bahan masukan bagi para guru dalam menyusun perangkat pembelajaran matematika. Diseminasi ini dilakukan dengan cara memberikan produk yang telah dihasilkan kepada guru-guru matematika di sekolah tempat uji coba produk dilaksanakan yaitu SMP N 2 Rumpin. Program diseminasi lanjutan dari produk yang dihasilkan dilakukan melalui forum MGMP kabupaten Bogor, mengunggah produk ke dalam blog pribadi, dan mengunggah produk ke dalam website sekolah. Produk yang telah dikembangkan ini dapat diakses dari peneliti secara langsung, Universitas Negeri Yogyakarta, dan SMP N 2 Rumpin Kabupaten Bogor.
Pengembangan perangkat pembelajaran matematika dengan pendekatan saintifik ini hanya dilakukan untuk SMP kelas VII semester genap, sehingga perangkat pembelajaran matematika dengan pendekatan saintifik dapat dikembangkan lagi untuk jenjang yang lain dengan prosedur yang serupa.

\section{DAFTAR PUSTAKA}

D'Amico, J, \& Gallaway, K. (2010). Differentiated instruction for the middle school science teacher: Activities and strategies for an inclusive classroom. San Francisco: Jossey-Bass.

Depdiknas. (2005). Undang-Undang RI No. 14 Tahun 2005 tentang Guru dan Dosen.

Gay, L.R. (1981). Educational research: competencies for analysis \& application $\left(2^{\text {nd }} e d.\right)$. Columbus: Charles E. Merrill Publishing Co.

Huitt, W. (2003). Classroom instruction. Educational Psychology Interactive. Valdosta, GA: Valdosta State University. Diakses pada tanggal 10 Oktober 2014 dari http://www.edpsycinteractive.org/topics/instruct.

Kementerian Pendidikan dan Kebudayaan. (2013). Materi pelatihan guru: implementasi kurikulum 2013 SMP/MTs matematika. Jakarta: Badan Pengembangan SDM Pendidikan dan Kebudayaan dan Penjaminan Mutu Pendidikan.

Kementerian Pendidikan dan Kebudayaan. (2014). Peraturan Menteri Pendidikan dan Kebudayaan Nomor 58 Tahun 2014 tentang Kurikulum 2013 SMP/MTs Bagian Pedoman Mata Pelajaran (PMP) Matematika.

Kementerian Pendidikan dan Kebudayaan. (2014). Peraturan Menteri Pendidikan dan Kebudayaan Nomor 103 Tahun 2014 tentang Pembelajaran pada Pendidikan Dasar dan Pendidikan Menengah.

Kennedy, L.M., et al. (2008). Guiding children's learning of mathematics. Belmont: Thomson Higher Education.

Muslich, M. (2007). KTSP: dasar pemahaman dan pengembangan. Jakarta: Bumi Aksara. 
Nwike, M., \& Catherine, O. (2013). Effects of use of instructional materials on students cognitive achievement in agricultural science. Journal of Educational and Social Research, 3(5), 103-107.

Ormrod, J.E. (2003). Educational psychology: developing learners. Ohio: Merrill Prentice Hall.

Rusindrayanti. (2015). Implementasi pendekatan saintifik dalam mata pelajaran matematika kelas VII tahun pelajaran 2013/2014 pada kurikulum 2013 di Daerah Istimewa Yogyakarta. E-jurnal Program Pascasarjana Universitas Negeri Yogyakarta Program Studi Pendidikan Matematika. Diakses pada tanggal 4 Agustus 2015 dari www.pps.uny.ac.id.

Schunk, D.H. (2012). Learning theories an educational perspective. Boston: Pearson Education, Inc.
Slavin, R. E. (2006). Educational psychology theory and practice $\left(8^{\text {th }} \mathrm{ed}\right.$.). Boston: Pearson Education, Inc

Sukmadinata, N.S. (2006). Metode penelitian pendidikan. Bandung: PT Remaja Rosdakarya.

Thiagarajan, et al. (1974). Instructional development for training teachers of exceptional children. Bloomington Indiana: Center of Innovation in Teaching the Handicapped.

Uno, H.B. (2014). Perencanaan pembelajaran. Jakarta: PT Bumi Aksara.

Widoyoko, E.P. (2014). Evaluasi program pembelajaran: panduan praktis bagi pendidik dan calon pendidik. Yogyakarta: Pustaka Pelajar.. 